\title{
STUDY OF FLOW IN VADOSE ZONE FROM ELECTRICAL RESISTIVITY SURVEYS
}

\author{
Fernando de Morais ${ }^{1}$, Luis de Almeida Prado Bacellar ${ }^{2}$ and Paulo Roberto Antunes Aranha ${ }^{3}$ \\ Recebido em 25 maio, 2007 / Aceito em 9 abril, 2008 \\ Received on May 25, 2007 / Accepted on April 9, 2008
}

\begin{abstract}
Among the indirect methods applied to environmental monitoring, electrical resistivity has played an important role in accessing water flow in the nonsaturated zone of the soil and, consequently, aquifer recharge. This work evaluates the influence of some pedo-geomorphologic properties in the infiltration and percolation of water through the superficial soil horizons by means of multitemporal electrical resistivity sections. The experiments were carried out in two areas of distinct pedogeomorphological characteristics developed on the crystalline basement of southeastern Brazil. The first is situated in a hollow-shaped slope where lixisols predominate; the second, in a nose-shaped slope where well-developed soils (ferra/so/s) predominate. The results proved the efficiency of the electrical resistivity method to delimit percolation of tropical soils, even when subtle differences are found in the hydraulic properties of the soil. It was also possible to establish that in the nose slope percolation is faster than in the hollow.
\end{abstract}

Keywords: electrical resistivity, hydraulic properties, groundwater, tropical soils.

RESUMO. Entre os métodos indiretos aplicados ao monitoramento ambiental, a eletrorresistividade tem desempenhado um papel importante no entendimento do fluxo de água na zona não saturada dos solos e, conseqüentemente, na recarga dos aqǘferos. Neste trabalho, pretende-se avaliar a influência de algumas propriedades pedogeomorfológicas na infiltração e percolação de água pelos horizontes superficiais dos solos por meio de seções de eletrorresistividade multitemporais. Os experimentos foram efetuados em duas áreas com características pedo-geomorfológicas distintas em região com rochas do embasamento cristalino do sudeste do Brasil. A primeira é situada numa encosta com formas côncavas em planta e em perfil (cabeceira de drenagem anfiteátrica), com predomínio de argissolos. A segunda área se situa numa encosta com forma convexa em planta e em perfil, com predomínio de latossolos. Os resultados provam a eficiência da eletrorresitividade para identificar percolação em solos tropicais, mesmo quando há diferenças sutis das propriedades hidráulicas. Foi também possível confirmar que a percolação é mais rápida na encosta com forma convexa do que na encosta com forma côncava.

Palavras-chave: eletrorresistividade, propriedades hidráulicas, água subterrânea, solos tropicais.

\footnotetext{
${ }_{1}^{1}$ Departamento de Geografia, Universidade Federal do Tocantins, Campus de Porto Nacional, Rua 7 s/n, Jardim dos Ipês, 77500-000 Porto Nacional, T0, Brazil. Phone: 55 (63) 3363-0500; Fax: (63) 3363-0509 - E-mail: moraisgeographer@gmail.com

${ }^{2}$ Departamento de Geologia, Escola de Minas, Universidade Federal de Ouro Preto, Campus Morro do Cruzeiro s/n, 35400-000 Ouro Preto, MG, Brazil. Phone: 55 (31) 3559-1602; Fax: (31) 3559-1600 - E-mail: luisapbacellar@gmail.com

3 Instituto de Geociências, Departamento de Geologia, Universidade Federal de Minas Gerais, Av. Presidente Antônio Carlos, 6.627, Pampulha, $31270-901$ Belo Horizonte, MG, Brazil. Phone: 55 (31) 3499-5442; Fax: (31) 3499-3410 - E-mail: aranha@igc.ufmg.br
} 


\section{INTRODUCTION}

With the growing of environmental issues, the awareness with the quality and availability of water has increased.

Among the indirect methods applied to environmental monitoring, electrical resistivity has played an important role in accessing the advance of contamination plumes in sanitary landfills, petrochemical complexes and cemeteries, among others (Lima et al., 1995; Depountis et al., 2005). This method has also been applied to access water flow in the non-saturated zone of the soil (Daily et al., 1992; Park, 1998; Hagrey \& Michaelsen, 1999; Mukhtar et al., 2000; Neves, 2002; Acworth et al., 2005), once resistivity decreases as moisture or the content of dissolved solids in the interstitial water increases (Nascimento et al., 1999).

According to Orellana (1972), electrical resistivity is the specific resistance of a body to let electric current pass through it. This property is based on Ohm's law, which states that if the injected current (I), the voltage $(\Delta V)$ and the position of current injection and potential points (current and voltage electrodes respectively) are known, resistivity is calculated with the equation:

$$
\rho=\left(\frac{\Delta V}{I}\right) \cdot K
$$

where, $K$ is a geometric factor dependent on the spatial arrangement of current $(A B)$ and voltage (MN) electrodes.

$$
K=2 \pi \cdot G x
$$

where, $x$ is the spacing adopted for AB and MN dipoles; and $n$ is a depth factor of the survey, and

$$
G=\frac{1}{(1 / n)-(2 / n+1)+(1 / n+2)}
$$

It is assumed in Equation 1 that the electric currents are applied to homogeneous and isotropic terrains; in other words, whatever the electrode array, the electrodes are considered to be located in points of equal resistivity. However, this is not observed in nature; in fact, the values obtained represent an apparent resistivity $\left(\rho_{a}\right)$ (Orellana, 1972).

The main objective of this work is to evaluate the interference of some tropical soil properties in water percolation through superficial soil horizons by means of the electrical resistivity method. Morais \& Bacellar's (2006) hypothesis is also tested, which states that percolation and, consequently, aquifer recharge in convex features is faster than in concave forms of the landscape.

\section{PHYSIOGRAPHIC SETTING}

The experiments took place in soils developed on the crystalline basement of the Quadrilátero Ferrífero (Bação Complex), between Ouro Preto and Belo Horizonte cities, central-southern Minas Gerais State (Fig. 1). Two areas were selected, one close to the Dom Bosco High School (Dom Bosco station) and another in the vicinity of the Holanda creek (Holanda station). The amount of information on pedogenesis, geomorphologic evolution, geotechnical characteristics and soil conservation is large for these areas (Parzanese, 1991; Bacellar, 2000; Silva, 2000; Santos, 2001; Sobreira, 2000; Futai, 2002; Morais, 2003). The climate, according to Koppen's classification, is of the Cwa-type, with marked annual rainfall contrast. Average annual rainfall is 1,348 mm, concentrated between October and March; average annual temperatures of $19^{\circ} \mathrm{C}$ (Santos, 2001), and average monthly evapotranspiration of $74 \mathrm{~mm}$ (Parzanese, 1991).

Finely-banded gneisses of predominantly granodioritic composition occur in both areas (Dorr, 1969). The weathering mantle is usually very thick, reaching up to $50 \mathrm{~m}$. The relief is smooth, with hills and mounts up to 70-m high (Bacellar, 2000). According to Hack \& Goodlet's (1960) models, the Dom Bosco station area is constituted by a concave-shaped slope in plan and section views (hollow), whereas the Holanda station area is convex-shaped in plan and section views (nose).

The primary vegetation is dominated by savanna (campos cerrados) replaced at present by very and moderately degraded pastures, respectively at the Holanda and Dom Bosco stations (Farias, 1992).

Soil horizon B predominantly contains quartz, kaolinite and gibbsite (Parzanese, 1991; Morais \& Bacellar, 2006) and secondarily goethite, illite, mica, silica and amorphous Al oxides and free Fe (Futai, 2002). Horizon A is more enriched in organic matter.

In the less steep sectors of the landscape, well-developed soils (ferralsols) occur, whereas in the geodynamically younger sectors lixisols and cambisols predominate (Parzanese, 1991; Bacellar, 2000). For these reasons, ferralsols are more common in the Holanda station nose, whereas lixisols occur in the Dom Bosco station hollow, with a ca. $60 \mathrm{~cm}$ deep, less permeable, clayey B horizon (textural $B$ ) (Morais \& Bacellar, 2006).

At the Holanda station, Bacellar (2000) identified cambisols by means of drill holes and GeoRadar. These soils develop on a less weathering-resistant, more quartz-rich variety of gneiss. They are characterized by a stony, weakly-developed horizon B (cambic 


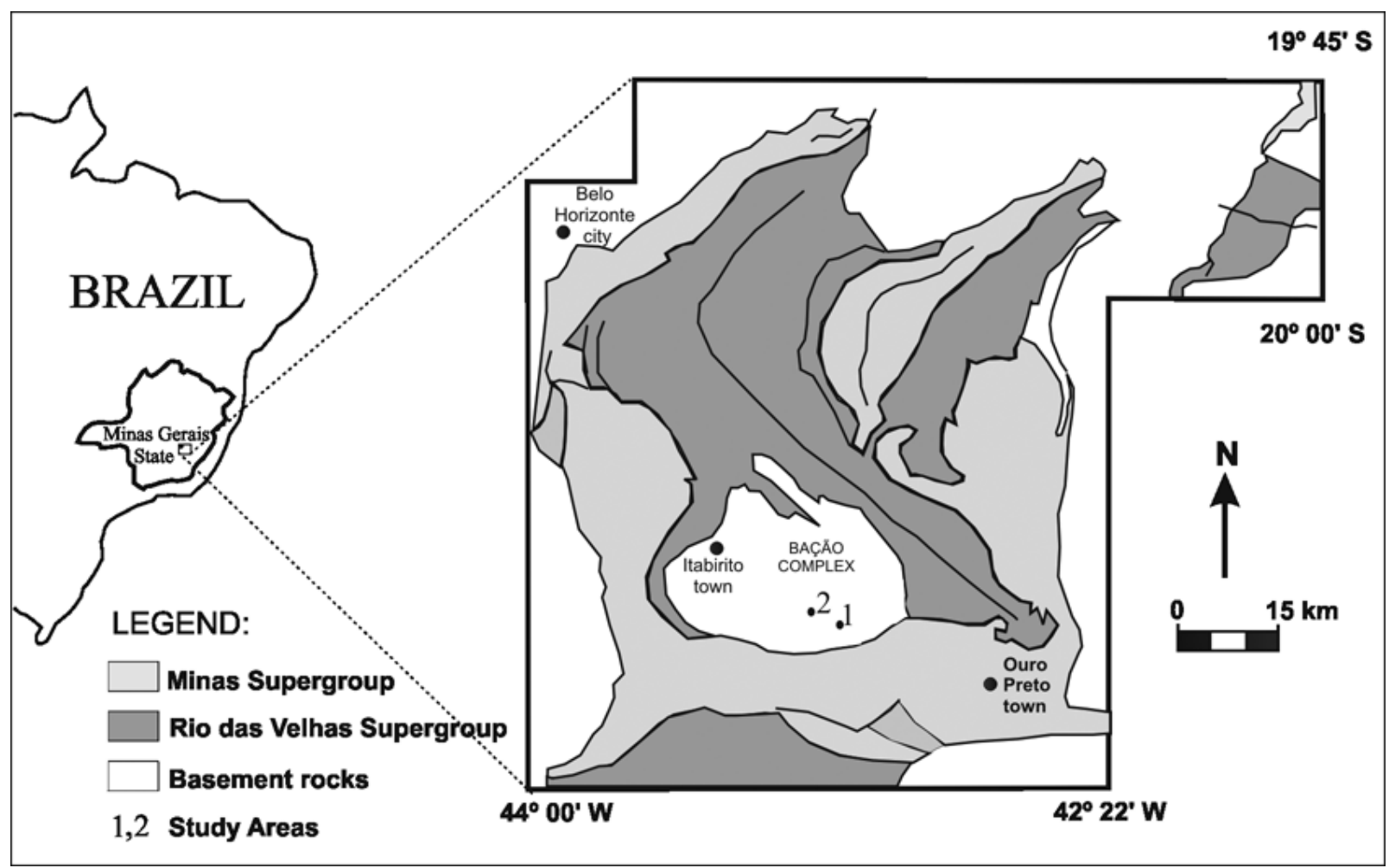

Figure 1 - Location of the study areas in the Bação Complex, Minas Gerais State, (1) Dom Bosco station; (2) Holanda station.

$B$ ) of high hydraulic conductivity, overlying a very fractured, but weakly-altered rock (Morais \& Bacellar, 2006).

Excepting the cambisols, the texture of the Holanda station soils are characteristically very fine, with clay contents $>37 \%$. At the Dom Bosco station, clay contents are less, excepting the points situated in the hollow external limit (Morais \& Bacellar, 2006), which show transition characteristics to ferra/so/s that occur in the noses.

Grain-size determinations carried out without the use of deflocculants yielded clay-free, sandy texture for these soils, due to the strong aggregation caused by $\mathrm{Fe}$ and $\mathrm{Al}$ oxy-hydroxides (Parzanese, 1991; Bacellar, 2000; Silva, 2000; Futai, 2002).

At the Holanda station, Morais \& Bacellar (2006) obtained average hydraulic conductivity values of $2.20 \times 10^{-5} \mathrm{~m} / \mathrm{s}$ and $2.09 \times 10^{-5} \mathrm{~m} / \mathrm{s}$ for $0.15-\mathrm{m}$ (horizon A) and 0.50-m (horizon B) depths respectively. At the Dom Bosco station, the average values were $1.44 \times 10^{-5} \mathrm{~m} / \mathrm{s}$ and $6.70 \times 10^{-6} \mathrm{~m} / \mathrm{s}$ for $0.15-\mathrm{m}$ (horizon A) and 0.50-m (horizon B) depths respectively, suggesting a slower percolation in the lixisols of the hollows than in the ferralsols of the noses. The Holanda station cambiso/ presents higher hydraulic conductivity values due to its coarser-grained texture (Morais \& Bacellar, 2006).

\section{METHODS}

Based on Morais \& Bacellar's (2006) works, four points were chosen, DB10 and DB27 at the Dom Bosco station and H03 and $\mathrm{H} 18$ at the Holanda station. Point H18 is a typical ferra/sol, whereas point H03 is a cambisol. Point DB27 is a typical lixiso/ of the Dom Bosco station hollow, whereas point DB10 has a transition behavior to ferralsol, because it is situated in the external limit of the hollow. The superficial soil horizons at these points yielded contrasting hydraulic conductivity values, in the following order: H03>H18>DB10>DB27 (Morais \& Bacellar, 2006).

In order to monitor infiltration and percolation, water saturated in $\mathrm{NaCl}$ was injected in each point using a $15 \mathrm{~cm}$ diameter cylinder under $30 \mathrm{~cm}$ hydraulic load (flooded condition). A total of 40 liters of saturated $\mathrm{NaCl}$ solution ( 0,05 ohm.m) were injected for a period of 24 hours, except at point DB27, where the soils are less permeable and only 20 liters could be injected during the same period.

Electrical resistivity surveys were carried out at these points using the continuous current meter TDC 1000-12R2A (Tectrol) with non-polarizable voltage electrodes. In each point, a 13-m line was delimited, with 1-m spacing between electrodes arranged 


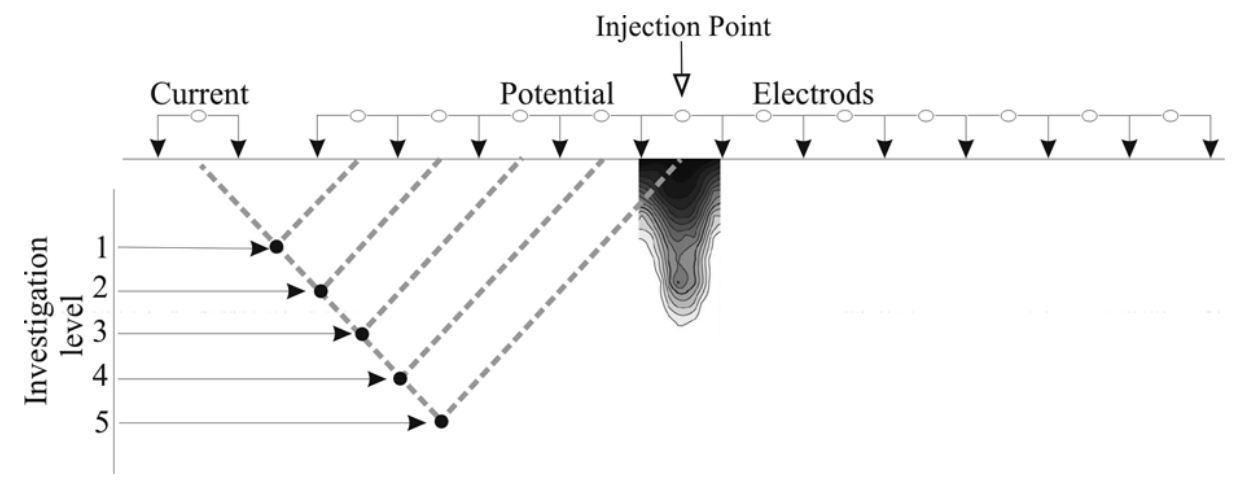

Figure 2 - Configuration of the dipole-dipole array and saline solution injection points.

according to dipole-dipole array, totaling 5 investigation levels (Fig. 2). The saline solution injection point was located in the center of the line.

Before the injection of the saline solution, a preliminary survey was carried out at each point, in order to obtain electric resistivity values for natural conditions (background) to be compared with the following surveys. After the injection of the solution, sections were obtained at certain time intervals, the first in the same day, one hour after the beginning of the injection, and the others 1, 8, 11 and 26 days later.

The apparent resistivity values obtained in the field were treated by means of the software RES2DINV, which transforms in quantitative data the qualitative positioning supplied by the pseudo-depth sections. Such transformation corresponds to mathematical inversions resultant from the application of the minimum-square smoothing method (Loke \& Barker, 1996). According to Samouëlian et al. (2003), inversion takes place in three stages: firstly, the field data constitute a pseudo-section; secondly, the data are calculated, and thirdly, adjustments are made between the measures and calculated data in order to reduce the differences between them, yielding a result closer to real (Fig. 3). The calculation of these differences is by root mean square error (RMS error, Eq. 4).

$$
R M S E=\sqrt{\frac{1}{n}} \sum_{i=1}^{n}(\rho c-\rho m)^{2}
$$

where:

$\rho c$ is the calculated apparent resistivity;

$\rho m$ is the measured resistivity;

$n$ is the number of points surveyed.

Loke \& Barker (1996) showed that from five iterations the error percentage tends to stabilize; therefore, the data were inverted with seven 7 iterations.

\section{RESULTS AND DISCUSSION}

Figures 4 and 5 represent the sections with the resistivity inversion models for the points of the Dom Bosco and Holanda stations, respectively.

The resistivity values, measured before injection of the saline solution, define the background intervals between 21-9,931; 482-1,628; 122-16,100 and 3,796-11,181 $\Omega$.m. for the profiles centered at points DB10, DB27, H3 and H18, respectively (Figs. 4 and 5). Thus, lower values in the following surveys would represent anomalies associated with the presence of saline solution.

Point DB27 (Fig. 4) exhibits lower resistivity values, due to its position inside the hollow, which is a more humid area subject to a natural convergence of superficial and sub-superficial flows (Coelho Netto, 1998). The low resistivity values (350-658 $\Omega . m$ ) at the fifth survey level correspond to a less deep water table at this point. Values higher than 1,528 $\Omega$.m between the second and the forth levels can be attributed to the less porous, less permeable soil horizon (textural $B$ horizon), starting at a 0.6-m depth (Morais \& Bacellar, 2006).

The highest resistivity values $(5,738-21,000 \Omega . m)$ found from the third survey level at point $\mathrm{H} 03$ are explained by the considerable abundance of rock fragments in the cambic horizon or by underlying altered rock crosscut by fractures. These electric resistivity values agree with those typical of gneisses, which vary from $6.8 \times 10^{4}$ to $3.0 \times 10^{6} \Omega$.m, depending on the moisture content (Telford et al., 1990). Bacellar (2000), on the other hand, related resistivity values less than $6,000 \Omega$.m to the saprolites of the area, while higher values were associated with fresh rock.

The values obtained for the salt-saturated area are those found between the electrodes 6 and $7 \mathrm{~m}$ of the sections, with apparent resistivity values of $<1,500 ;<1,003 ;<2,416$ and $<3,266 \Omega$.m for points DB10, DB27, H03 and H18 respectively (Figs. 4 and 5 ). The saline solution plume is easily dis- 

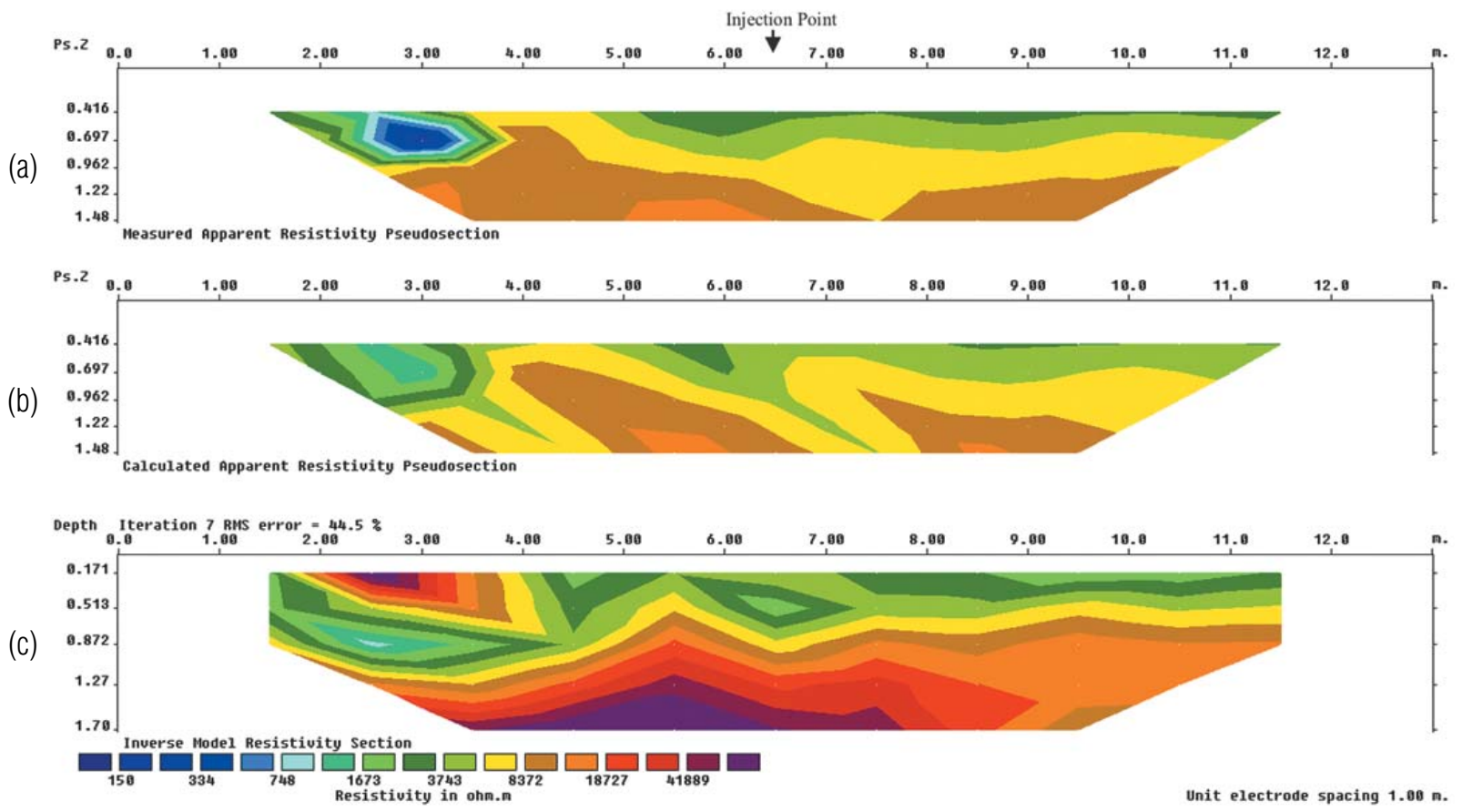

Figure 3 - Hypothetical sections elaborated during the mathematical inversion process. (a) field section; (b) calculated section; (c) inverted section.

tinguishable from the second day on, at points DB10, $\mathrm{HO}$ and $\mathrm{H} 18$, and on the 9th day at point DB27.

From the low resistivity values corresponding to the percolation of the saline solution, it is possible to observe that the vertical flow was faster at the Holanda station soils than in those of the Dom Bosco station (Figs. 4 and 5). These variations corroborate and reinforce Morais \& Bacellar's (2006) hypothesis, which states that in the hollows (Dom Bosco station) percolation is slower than in the noses (Holanda station), due to lower hydraulic conductivity values of the superficial horizons.

The vertical flow velocity at point $\mathrm{H} 03$ was higher (Fig. 5), which is explained by the high hydraulic conductivity values in the cambic horizon. At point $\mathrm{H} 18$ the vertical flow velocity was smaller, despite a significant oblique flow (between electrodes 4 and 6, after the 2nd day of the experiment - Fig. 5). At point DB10 the vertical flow velocity was even lower. Although not as evident as at point $\mathrm{H} 18$, a reduction of the resistivity oblique to the injection point (between electrodes 3 and 6 and 7 and 10, after the 2nd day of the experiment - Fig. 5) was also observed. In the trenches dug after the experiments, it was verified that this oblique flow could have followed cavities made by ants and termites. It is worth mentioning that the soils of points DB10 and $\mathrm{H} 18$ have high clay contents (Morais \& Bacellar, 2006), thus keeping these cavities open by cohesion.
Comparisons with point DB27 are more difficult, because at this point half of the volume of saline solution was introduced, due to the lower hydraulic conductivity of the soils. It is verified, however, that the rate between the width of the lateral flow and the depth of the vertical flow is lower at this point than in other points, which agrees with the more impermeable textural $B$ horizon at $c a$. $60 \mathrm{~cm}$. Therefore for this point located inside the hollow, the possibility of generation of shallow sub-superficial flows is higher.

As in other studies (Hagrey \& Michaelsen, 1999; Neves, 2002), in this work the electrical resistivity method proved efficient for studies of the water flow in vadose zones. It is worth stressing out that, due to the small number of electrodes available, the electrodes were removed after each experiment and replaced at the same site for the next survey. This procedure did not interfere with the results obtained.

\section{CONCLUSIONS}

With the objective of evaluating infiltration and percolation in superficial soil horizons, multitemporal electric resistivity sections were obtained for each point of both study areas.

The electrical resistivity method proved efficient to evaluate flows in the non-saturated zone of tropical soils of the study areas 


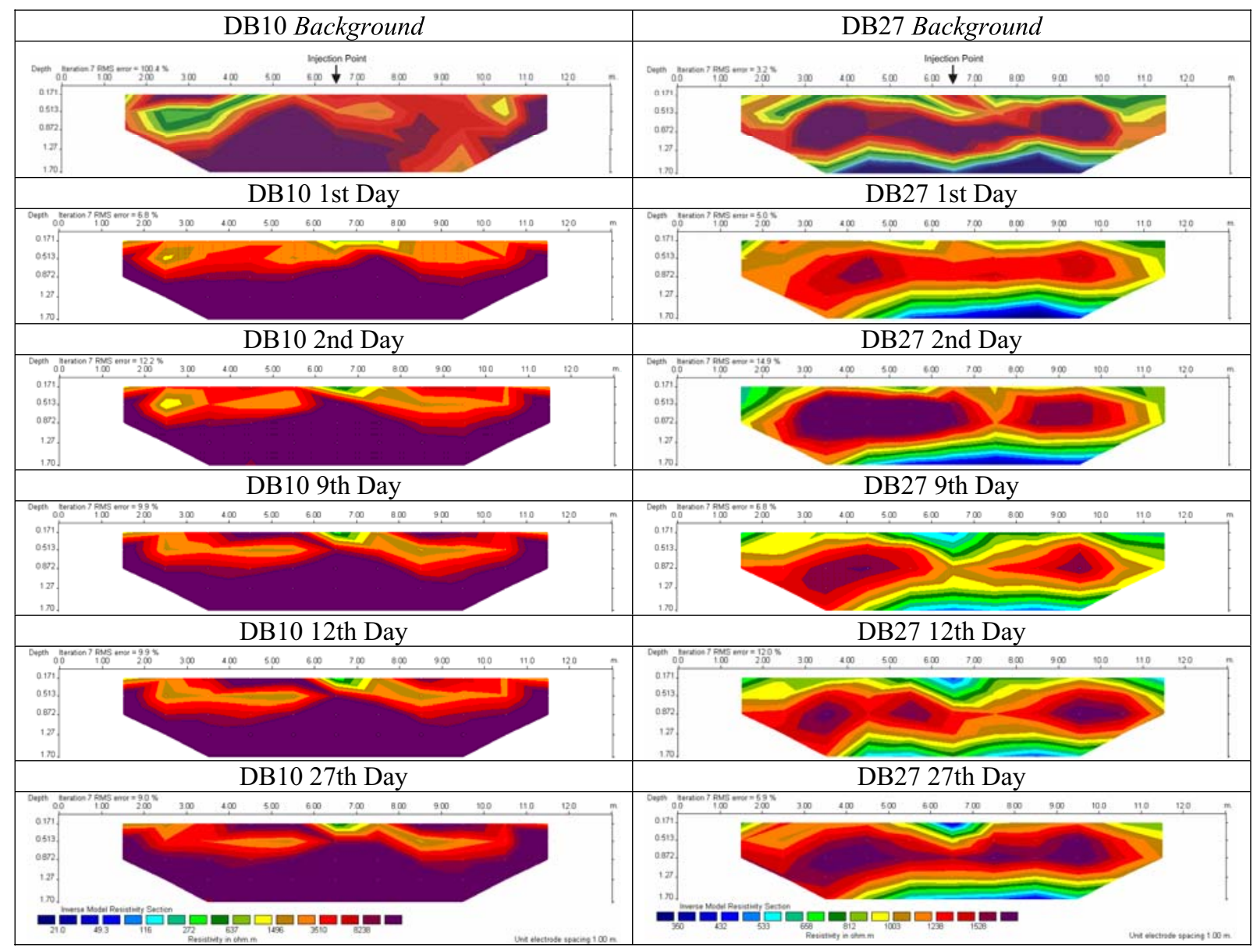

Figure 4 - Multitemporal inversion-model resistivity sections at Dom Bosco station.

and the results obtained agree with the hydraulic conductivity values of their horizons.

The presence of macropores of biologic origin significantly influences percolation. Previous results that showed that percolation is faster in more developed soils of the nose than in those of the hollow were also confirmed, which would make these areas more favorable for aquifer recharge.

\section{ACKNOWLEDGEMENTS}

We wish to thank FAPEMIG for the financial support to this work (project TEC-760/05). The first author is grateful to CAPES for the D.Sc. scholarship.

\section{REFERENCES}

ACWORTH RI, YOUNG RR \& BERNADI AL. 2005. Monitoring soil moisture status in a Black Vertosol on the Liverpool Plains, NSW, using a combination of neutron scattering and electrical image methods.
Australian Journal of Soil Research, 43: 105-117.

BACELLAR LAP. 2000. Condicionantes Geológicos, Geomorfológicos e Geotécnicos dos mecanismos de voçorocamento na Bacia do Rio Maracujá, Ouro Preto, MG. D.Sc. Thesis COPPE, Federal University of Rio de Janeiro, Brazil. $226 \mathrm{p}$.

COELHO NETTO AL. 1998. Hidrologia de encosta na interface com a geomorfologia. In: GUERRA AJT \& CUNHA SB (Ed.). Geomorfologia - Uma atualização de bases e conceitos. Bertrand, Rio de Janeiro, ISBN 85-286-0326-1. p. 93-148.

DAILY W, RAMIREZ A, LABRECQUE D \& NITAO J. 1992. Electrical resistivity tomography of vadose water movement. Water Resource Research, 28(5): 1429-1442.

DEPOUNTIS N, HARRIS C, DAVIES MCR, KOUKIS G \& SABATAKAKIS N. 2005. Application of electrical imaging to leachate plume evolution studies under in-situ and model conditions. Environmental Geology, 47: 907-914.

DORR JVN. 1969. Physiographic, stratigraphic, and structural develop- 


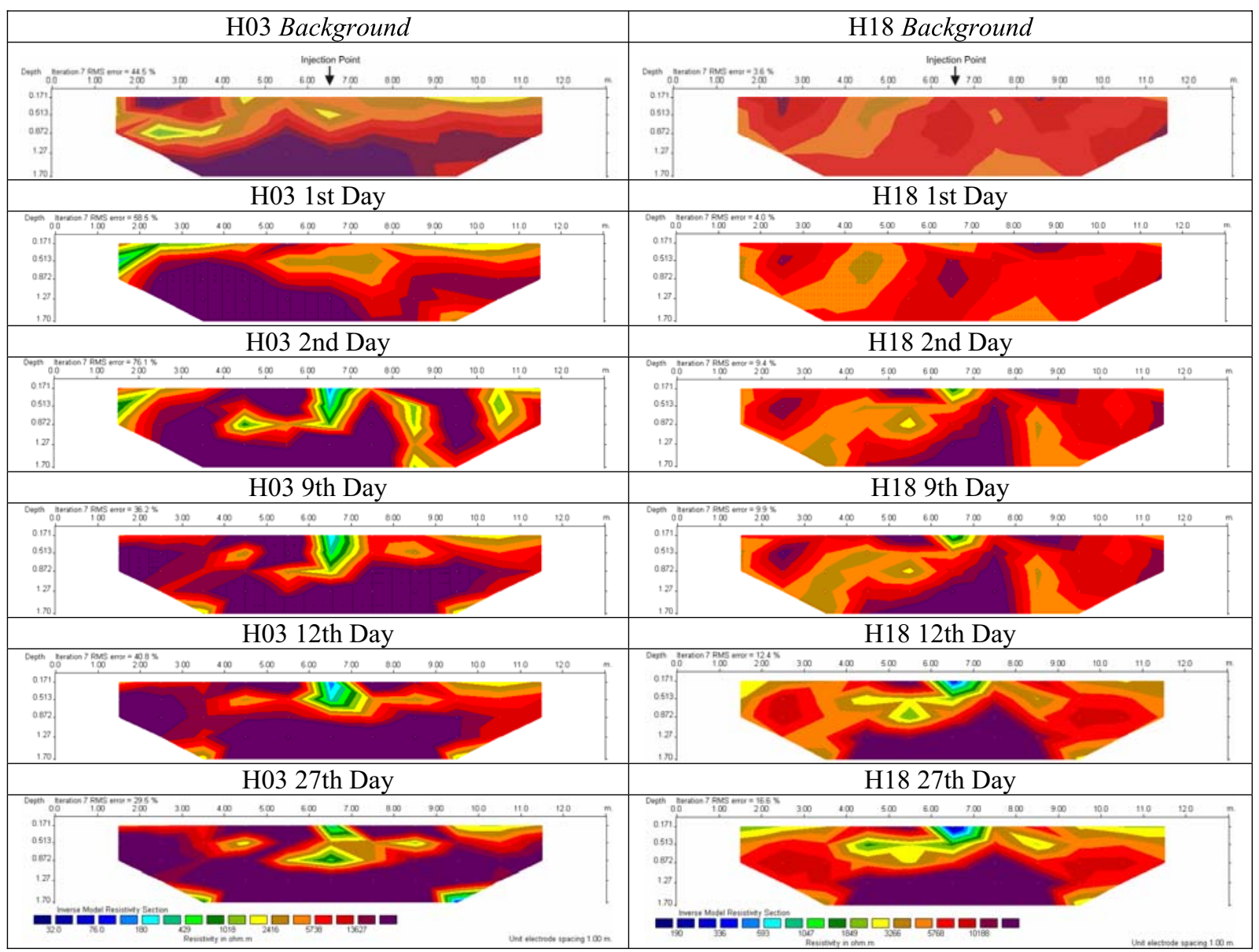

Figure $\mathbf{5}$ - Multitemporal inversion-model resistivity sections at Holanda station.

ment of the Quadrilátero Ferrífero, Minas Gerais, Brazil. U.S. Geological Survey Professional Paper, 641-A: $110 \mathrm{p}$.

FARIAS CA. 1992. Dinâmica da revegetação natural de voçorocas na região de Cachoeira do Campo, MG. MSc. Thesis, Federal University of Viçosa, Brazil. 63 p.

FUTAI MM. 2002. Estudo teórico-experimental do comportamento de solos tropicais não-saturados: Aplicação a um caso de voçorocamento. D.Sc. Thesis COPPE, Federal University of Rio de Janeiro, Brazil. 559 p.

HACK JT \& GOODLET JG. 1960. Geomorphology and forest ecology of a mountain region in the Central Appalachians. U.S. Geological Survey Professional Paper, 347: 66p.

HAGREY SA \& MICHAELSEN J. 1999. Resistivity and percolation study of preferential flow vadose zone at Bokhorst, Germany. Geophysics, 64(3): 746-753.

LIMA OAL, SATO HK \& PORSANI MJ. 1995. Imaging industrial contaminant plumes with resistivity techniques. Journal of Applied Geophysics, 34: 93-108.
LOKE MH \& BARKER RD. 1996. Rapid least-squares inversion of apparent resistivity pseudosections by a quasi-Newton method. Geophysical Prospecting, 44: 131-152.

MORAIS F. 2003. Estudo dos Processos Erosivos Subsuperficiais na Bacia do Rio Maracujá - MG. MSc. Thesis, Federal University of Ouro Preto, Brazil. $98 \mathrm{p}$.

MORAIS F \& BACELLAR LAP. 2006. Análise dos fatores intervenientes na condutividade hidráulica dos horizontes superficiais de solos de áreas gnáissicas do complexo Bação - MG. Solos e Rochas, 29(1): 89-101.

MUKHTAR AL, SULAIMAN WN, IBRAHIM S, LATIF PA \& HANAFI MM. 2000. Detection of groundwater pollution using resistivity imaging at Seri Petaling landfill, Malaysia. Journal of Environmental Hydrology, 8: $1-7$.

NASCIMENTO CTC, KOIDE S, PIRES ACB \& MELLO GA. 1999. Pseudoseções elétricas na avaliação da contaminação do subsolo. Revista Brasileira de Geociências, 29(4): 621-626.

NEVES APV. 2002. Estudo geofísico para a caracterização geológica e 
hidrogeológica da subsuperfície rasa em área de deposição de rejeitos sólidos no município de Barcarena - PA. MSc. Thesis, Federal University of Pará, Brazil. 50 p.

ORELLANA E. 1972. Prospección geoeléctrica en corriente continua Ed. Paraninfo, 523p.

PARK S. 1998. Fluid migration in the vadose zone from 3-D inversion of resistivity monitoring data. Geophysics, 63(1): 41-51.

PARZANESE GAC. 1991. Gênese e desenvolvimento de voçorocas em solos originados de rochas granitóides na região de Cachoeira do Campo, Minas Gerais. MSc. Thesis, Federal University of Viçosa, Brazil. $117 \mathrm{p}$.

SAMOUËLIAN A, COUSIN I, RICHARD G, TABBAGH A \& BRUAND A. 2003. Electrical resistivity imaging for detecting soil cracking at the cen- timetric scale. Soil Science Society America Journal, 67(5): 1319-1326.

SANTOS CA. 2001. Comportamento Hidrológico Superficial, Subsuperficial e a Erodibilidade dos solos da região de Santo Antônio do Leite, distrito de Ouro Preto - MG. MSc. Thesis, Federal University of Ouro Preto, Brazil. 108 p.

SILVA TRM. 2000. Caracterização e erodibilidade dos solos de uma voçoroca na região de Ouro Preto - MG. MSc. Thesis, Federal University of Rio de Janeiro, Brazil. $106 \mathrm{p}$.

SOBREIRA FG. 2000. Processos erosivos acelerados (voçorocas): 0 exemplo de Cachoeira do Campo, Ouro Preto, MG. Solos e Rochas, 23(3): 217-233.

TELFORD WM, GELDART LP \& SHERIFF RE. 1990. Applied Geophysics. Cambridge University Press, $770 \mathrm{p}$.

\section{NOTES ABOUT THE AUTHORS}

Fernando de Morais. Graduated in Geography, Federal University of Tocantins (2001). MSc (2003) and PhD (2007) in Natural Sciences, Federal University of Ouro Preto. Visiting Researcher (2007) at Centro de Tecnologia Mineral - CETEM, Rio de Janeiro, RJ. Professor at Federal University of Tocantins since 2008.

Luis de Almeida Prado Bacellar. Graduated in Geology (1985) by University of São Paulo (USP). MSc in Structural Geology, Federal University of Ouro Preto (1987) and DSc in Environmental Geotechnics, COPPE/UFRJ (2000). Worked as a Geologist at ABCP - Brazilian Portland Cement Association (1985/1987) and at PETROBRAS (1989/2004). Since 2004 professor at the Geology Department of the School of Mines, Federal University of Ouro Preto.

Paulo Roberto Antunes Aranha. Specialization in Computing Sciences in Federal University of Minas Gerais (1992). MSc in Geophysics, Federal University of Bahia (1991) and PhD in Natural Sciences, Federal University of Ouro Preto. Since 2004 professor at the Geology Department of Federal University of Minas Gerais. 